\title{
Pengaruh Frekuensi Pemberian Pakan terhadap Konsumsi Pakan, Pertambahan Berat Badan Harian dan Feed Conversion Ratio pada Ayam Ras Pedaging
}

\section{Effect of Feeding Frequency on Feed Intake, Average Daily Gain and Feed Conversion Ratio in Broiler}

\author{
Samlawi ${ }^{1}$, Rastosari $A^{1}$, Patria $C A^{1}$ \\ ${ }^{1}$ Fakultas Peternakan, Universitas Tulang Bawang Lampung, Jl. Gajah Mada, Bandar \\ Lampung \\ Samlawi73@gmail.com
}

\begin{abstract}
The purpose of this study was to determine the effect of feeding frequency on feed intake, average daily gain (ADG) and Feed Conversion Ratio (FCR) in broiler. The research method used in this study is the experimental method, which is the type of research used to find the effect of certain treatment against others in controlled conditions. This research was conducted on poultry breeding farm at Company Farm. Method of data collection used in this research using instrument that is observation sheet to get feed intake, average daily gain, and FCR. The data obtained were analyzed by using independent sample t-test test with SPSS version 17. 00 software. The feeding method did not affect feed intake, ADG and FCR. The average intake of chicken feed maintained by using the method of feeding 2 times was $59.33 \mathrm{~g}$ lower than using the method of feeding 3 times, namely $59.41 \mathrm{~g}$. The ADG by feeding method 2 times was $45.29 \mathrm{~g}$, while by feeding method 3 times was $46,21 \mathrm{~g}$. The value of FCR method of feeding 3 times is 1,286 , meaning that to produce $1 \mathrm{~kg}$ of meat requires $1,286 \mathrm{~kg}$ of feed. While the value of chicken FCR on feeding method 2 times is 1,311, that means to produce $1 \mathrm{~kg}$ of meat requires as much as $1,311 \mathrm{~kg}$ of feed.
\end{abstract}

Keywords: Average Daily Gain, Broiler, Feed Intake, Feed Conversion Ratio

\section{PENDAHULUAN}

Sektor peternakan sebagai yang strategis dalam pembangunan perekonomian Indonesia. Salah satu komoditas peternakan yang memiliki potensi yang cukup tinggi di Indonesia adalah peternakan ayam ras pedaging. Usaha peternakan ayam ras pedaging saat ini berkembang sangat pesat, baik dari segi skala usaha maupun dari segitingkat efisiennya. Ayam ras pedaging atau biasa disebut ayam ras pedaging merupakan ternak penghasil daging yang relative lebih cepat masa produksinya dibandingkan dengan ternak potong lainnya. Keunggulan ayam ras pedaging lain nya antara lain konversi pakan kecil, siap dipotong pada usia muda, serta menghasilkan kualitas daging berserat lunak. Karena itulah produksi ternak ayam ras pedaging saat ini berkembang pesat. Selain itu, jumlah permintaan daging ayam yang terus meningkat juga merupakan daya tarik tersendiri bagi para pelaku usaha untuk menekuni usaha peternakan ayam ayam ras pedaging ini.

Ayam ras pedaging merupakan salah satu jenis komoditi peternakan yang menghasilkan nilai gizi dan memiliki nilai ekonomi yang cukup potensial. Ayam ras pedaging merupakan sumber protein hewani terbesar bagi masyarakat Indonesia. Ayam ras pedaging merupakan jenis ayam ras pedaging unggul hasil perkawinan silang, seleksi dan rekayasa genetik dari bangsa-bangsa ayam yang 
memiliki produktivitas tinggi, terutama dalam hal produksi daging. Produksi ayam ras pedaging berkembang pesat seiring dengan pertambahan kebutuhan akan sumber pangan yang berasal dari hewani.

Berdasarkan data Badan Pusat Statistik (2016), produksi ayam ras pedaging di Indonesia tahun 2015 mengalami peningkatan dibanding produksi ayam ras pedaging tahun 2014 yaitu dari 1.544 .378 ton meningkat menjadi 1.627.107 ton. Propinsi Lampung merupakan salah satu propinsi yang juga menghasilkan produksi ayam ras pedaging di Indonesia.

Kabupaten Lampung Selatan merupakan kabupaten yang memberikan kontribusi terbesar untuk Propinsi Lampung dalam hal produksi daging ayam ras pedaging. Kontribusi Kabupaten Lampung Selatan dalam produksi daging ayam ras pedaging mencapai 44,33 persen dari total keseluruhan produksi daging ayam ras pedaging di Propinsi Lampung.

Keberhasilan usaha ayam ras pedaging sangat dipengaruhi oleh faktor pakan (feed), pembibitan (breeding), dan tatalaksana (manajemen). Saat ini industri ayam ayam ras pedaging menghadapi problema yang sangat mendesak, yaitu rendahnya efisiensi produktivitas. Faktor utama yang menyebabkan rendahnya efisiensi adalah mahalnya harga pakan. Hal ini dikarenakan biaya pakan pada industri ayam ayam ras pedaging menempati lebih dari setengah total biaya produksi. Oleh karena itu, diperlukan suatu cara yang aplikatif untuk mengatasi permasalahan tersebut.

Penghematan biaya pakan merupakan tujuan yang harus dicapai dalam mendapat keuntungan yang maksimal dari hasil produksinya. Kenaikan harga pakan sering tidak seimbang dengan harga produksi peternakan ayam, sehingga menyebabkan kelesuan peternak dalam meneruskan usahanya. Memilih cara pemberian pakan pada usaha peternakan ayam ayam ras pedaging merupakan faktor yang sangat menentukan bagi keberhasilan peternak, salah satunya yaitu dengan cara pembatasan pemberian pakan.

Pembatasan pemberian pakan merupakan program untuk memberikan pakan pada ternak sesuai dengan kebutuhan hidup pokoknya pada umur dan periode tertentu. Program ini didasarkan kepada asumsi bahwa pemberian pakan secara sepuasnya (ad libitum) merupakan kondisi buatan, sedangkan pembatasan pakan pada ayam ayam ras pedaging adalah upaya mengembalikan ternak pada kondisi alami. Banyak masalah yang cukup serius dan sering muncul pada pemeliharaan ayam pedaging terutama di daerah tropis, seperti kematian pada akhir pemeliharaan, perlemakan yang banyak, dan kelainan pada kaki.

Salah satu cara yang dapat dilakukan untuk mengatasi masalah tersebut adalah dengan pembatasan pakan, apakah dilakukan di awal pertumbuhan ataupun di masa akhir pertumbuhan. Keuntungan yang dapat diperoleh dari program pembatasan pakan adalah dapat mengurangi angka kematian, kelainan kaki, dan penyakit metabolik, seperti: ascites, stres panas atau bahkan meningkatkan daya kekebalan tubuh terhadap penyakit. Program pembatasan pakan juga menaikkan kandungan mineral tubuh serta menurunkan trigliserida dan kolesterol darah dan kadar lemak dalam tubuh dan daging.

\section{METODOLOGI PENELITIAN}

\section{Lokasi dan Waktu}

Penelitian ini telah dilakukan pada Farm Naryo yang berlokasi di Desa Way Gelam Kecamatan Candipuro Kabupaten Lampung Selatan. Penelitian ini 
dilaksanakan selama 21 hari yaitu dari tanggal 21 Agustus sampai 10 September 2017.

\section{Pengumpulan Data}

Pengumpulan data menggunakan instrument berupa lembar pengamatan (observasi) dengan pencatatan hasil pengamatan langsung di Farm Naryo terhadap 190 ekor ayam ras pedaging dengan dua perlakuan pemberian pakan yang berbeda. Perlakuan frekuensi pemberian pakan yang diberikan adalah :

P1 : 95 ekor ayam ras pedaging memperoleh perlakuan pemberian pakan dua kali dalam sehari (kontrol) yaitu pukul 07.00 WIB dan pukul 16.00 WIB dengan porsi $50 \%: 50 \%$ dari total kebutuhan harian.

P2 : 95 ekor ayam ras pedaging memperoleh perlakuan pemberian pakan tiga kali dalam sehari (penelitian) yaitu pukul $07.00 \mathrm{WIB}(30 \%)$, pukul 15.00 WIB (30\%), dan pukul 22.00 WIB (40\%).

Pengamatan mengenai pengaruh perlakuan dalam pemberian pakan tersebut terhadap konsumsi pakan yang akan dilakukan pencatatan di setiap akhir harinya selama 21 hari yaitu pada saat ayam ras pedaging berumur 0 hari sampai dengan 21 hari. Bibit ayam pada saat datang akan langsung dilakukan penimbangan. Sedangkan pencatatan pertambahan berat badan harian ayam ras pedaging akan dilakukan seminggu sekali.

\section{Analisis Data}

Data yang diperoleh dianalis dengan menggunakan uji independent samplel $t$-test dibantu dengan perangkat lunak SPSS version 17. 00 untuk $\mathrm{PBBH}$ dan konversi pakan. Kriteria pengambilan keputusan adalah apabila nilai probability $(p)<0,05$, maka ada pengaruh media pakan terhadap $\mathrm{PBBH}$ dan konversi pakan dan sebaliknya apabila nilai probability $(p)>0,05$, tidak ada pengaruh media pakan terhadap PBBH dan konversi pakan.

\section{Materi Alat dan Bahan}

Alat yang digunakan pada penelitian ini kandang, timbangan digital, tempat pakan, lampu, tempat minum otomatis (TMO), brooder dan sekat, alat pencatat, alat pemanas (gasolec), label ayam. Bahan yang digunakan meliputi ayam ras pedaging dengan strain Cobb CP-707 produksi PT. Cenrtal Avian Pertiwi (CAP) sebanyak 190 ekor dan pakan merek Hi-Pro BR1 H11 produksi PT Charoen Pokphand.

\section{HASIL PENELITIAN DAN PEMBAHASAN}

\section{Pengaruh Perlakuan terhadap Konsumsi Pakan (Feed Intake)}

Konsumsi pakan Feed Intake) merupakan jumlah pakan yang yang diberi awal dikurangi sisa pakan. Rata-rata konsumsi pakan ayam pada pemeliharaan dengan menggunakan frekuensi pemberian pakan 3 kali dan 2 kali disajikan pada Tabel 1 dan Gambar 1. 
Tabel 1. Konsumsi Pakan pada Pemeliharaan Ayam dengan Menggunakan Frekuensi Pemberian Pakan 3 Kali dan 2 Kali

\begin{tabular}{ccc}
\hline \multirow{2}{*}{ Umur (Hari) } & \multicolumn{2}{c}{$\begin{array}{c}\text { Konsumsi pakan per ekor (gr) dengan Menggunakan Dua } \\
\text { Frekuensi Pemberian Pakan }\end{array}$} \\
\cline { 2 - 3 } & $\mathbf{3}$ Kali & $\mathbf{2 ~ K a l i}$ \\
\hline 1 & 11,00 & 11,00 \\
3 & 11,00 & 11,00 \\
4 & 16,00 & 16,00 \\
5 & 16,00 & 16,00 \\
6 & 32,00 & 32,00 \\
7 & 32,00 & 32,00 \\
8 & 34,00 & 34,00 \\
9 & 43,00 & 43,00 \\
10 & 54,00 & 54,00 \\
11 & 54,00 & 54,00 \\
12 & 53,45 & 54,00 \\
13 & 64,50 & 64,50 \\
14 & 65,00 & 65,00 \\
15 & 65,00 & 64,00 \\
16 & 76,00 & 74,50 \\
17 & 91,00 & 91,00 \\
18 & 97,00 & 96,50 \\
19 & 103,00 & 102,42 \\
20 & 107,15 & 108,00 \\
21 & 108,00 & 108,00 \\
& 114,50 & 115,00 \\
\hline Jumlah & $\mathbf{1 2 4 7 , 6 0}$ & $\mathbf{1 2 4 5 , 9 2}$ \\
\hline Rata-rata & $\mathbf{5 9 , 4 1}$ & $\mathbf{5 9 , 3 3}$ \\
\hline Standar Deviasi & $\mathbf{3 4 , 1 4}$ & $\mathbf{3 4 , 1 3}$ \\
\hline
\end{tabular}

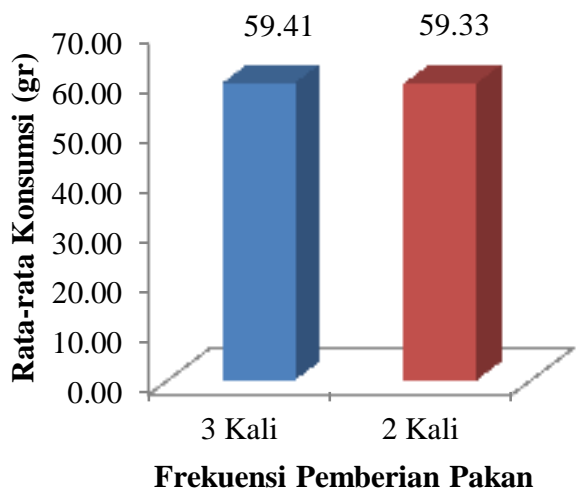

Gambar 1. Perbandingan Rata-rata Konsumsi Pakan pada Ayam yang Dipelihara dengan Menggunakan Frekuensi Pemberian Pakan 2 Kali

Berdasarkan hasil analisis melalui uji independent sample $t$ test menunjukkan bahwa perlakuan frekuensi pemberian pakan berpengaruh tidak nyata $(p>0.05)$ terhadap konsumsi pakan ayam ras pedaging. Hal ini menggambarkan tidak ada perbedaan konsumsi pakan antara ayam dipelihara dengan menggunakan frekuensi pemberian pakan 3 dan 2 kali. Rata-rata konsumsi seperti terlihat pada Gambar 14 pada ayam yang dipelihara dengan menggunakan metode pemberian pakan 3 kali ada 59,41 gram dan pada ayam 
dipelihara menggunakan frekuensi pemberian pakan 2 kali tidak memiliki perbedaan yang signifikan yaitu 59,33 gram.

Tidak adanya pengaruh frekuensi pemberian pakan terhadap konsumsi lebih disebabkan oleh pembatasan frekuensi pemberian pakan seharusnya memperhatikan suhu. Pada penelitian baik frekuensi pemberian pakan 3 kali dan 2 kali memiliki kondisi suhu yang sama. Hal inilah yang mungkin menyebabkan

Tidak adanya perbedaan konsumsi pakan pada masing-masing perlakuan. Tidak adanya pengaruh metode pemberian pakan ini sejalan dengan penelitian Idayat etal.(2012) yang menemukan bahwa frekuensi pemberian pakan 2 kali, 3 kali dan 4 kali tidak memberikan pengaruh nyata terhadap performa ayam ras pedaging. Hal ini di didukung Betty etal. (2015) dalam Rahmawati (2017) yang melaporkan bahwa pemberian pakan 2 kali (pukul 06:00 dan18:00 WIB), 3 kali (pukul 06:00,12:00 dan 18:00 WIB) dan 4 kali (pukul 06:00,10:00,14:00 dan 18:00) menunjukkan performa ayam pedaging yang tidak berbeda.

\section{Pengaruh Perlakuan Terhadap Bobot Badan dan Pertambahan Bobot Badan Harian (PBBH)}

Hasil penelitian rata-rata pertambahan bobot badan harian ayam pada pemeliharaan dengan menggunakan metode pemberian pakan 3 kali dan2 kali disajikan Tabel 2 dan Gambar 2 di bawah ini.

Tabel 2. Rata-rata Pertambahan Bobot Badan Harian pada pemeliharaan dengan Metode Pemberian Pakan 3 Kali dan 2 kali

\begin{tabular}{crr}
\hline & \multicolumn{2}{c}{$\begin{array}{c}\text { PBBH (gr) Ayam Ras Pedaging dengan Dua Metode } \\
\text { Pemberian Pakan }\end{array}$} \\
\cline { 2 - 3 } Umur (Hari) & \multicolumn{2}{c}{2 Kali } \\
\hline 1 & \multicolumn{3}{c}{ Kali } & - \\
7 & $21,61 \pm 0,87$ & $20,27 \pm 0,28$ \\
14 & $32,75 \pm 0,69$ & $32,19 \pm 0,76$ \\
21 & $46,210 \pm 1,05$ & $45,29 \pm 1,13$ \\
\hline Rerata & 46,21 & 45,29 \\
\hline
\end{tabular}

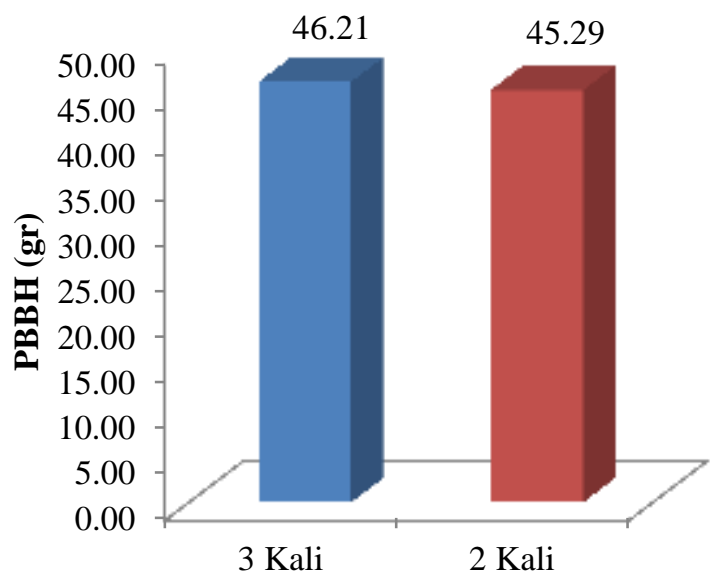

Frekuensi Pemberian Pakan

Gambar 2. Perbandingan Rata-rata Pertambahan Bobot Badan Harian Ayam yang dipelihara dengan menggunakan metode pemberian pakan 3 kali dan 2 kali 
Hasil analisis dengan menggunakan uji independent sample $t$ test menunjukkan bahwa perlakuan metode pemberian pakan berpengaruh tidak nyata $(p>0.05)$ terhadap pertambahan berat badan harian ayam ras pedaging. Hal ini menunjukkan tidak ada perbedaan PBBH antara ayam dipelihara dengan menggunakan metode pemberian pakan 3 kali dan 2 kali. Rata-rata PBBH ayam yang dipelihara dengan frekuensi pemberian pakan 3 kali adalah 46,21 gram dan pada ayam yang dipelihara dengan frekuensi pemberian pakan 2 kali adalah 45,29 gram. Tidak adanya pengaruh metode pemberian pakan terhadap PBBH lebih disebabkan oleh tingkat konsumsi pakan juga relative sama, sehingga $\mathrm{PBBH}$ juga relative sama.

Hasil penelitian ini sejalan dengan penelitian yang dilakukan oleh Julius (2013, dalam Handayani, 2014) bahwa performa ayam broiler tidak berbeda nyata pada semua perubahan dimana perubahan yang diamati meliputi komsumsi pakan, bobot badan akhir, pertambahan bobot badan, FCR, mortalitas dan indeks performa.

\section{Pengaruh Perlakuan Terhadap FCR}

Hasil penelitian besar nilai FCR pada ayam dengan pemeliharaan menggunakan metode pemberian pakan 3 kali dan 2 kali pada Gambar. 3 di bawah ini.

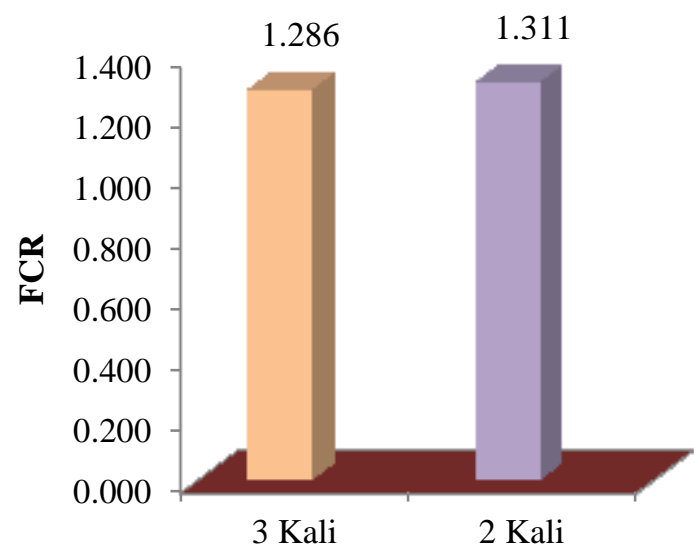

Frekuensi Pemberian Pakan

Gambar 3. Besarnya Nilai FCR Ayam yang dipelihara dengan menggunakan Frekuensi Pemberian Pakan 3 kali dan 2 Kali

Hasil analisis dengan menggunakan uji independent sample $t$ test menunjukkan bahwa perlakuan frekuensi pemberian pakan berpengaruh tidak nyata $(p>0.05)$ terhadap FCR pada ayam ras pedaging (broiler). Hal ini menunjukkan tidak ada perbedaan FCR antara ayam dipelihara dengan menggunakan frekuensi pemberian pakan 3 kali dan 2 kali. Rata-rata FCR ayam yang dipelihara dengan frekuensi pemberian pakan 3 kali adalah 1,286, artinya untuk menghasilkan $1 \mathrm{~kg}$ daging dibutuhkan pakan sebanyak $1,286 \mathrm{~kg}$, Sedangkan nilai FCR ayam pada frekuensi pemberian pakan 2 kali 1,311, artinya untuk menghasilkan $1 \mathrm{~kg}$ daging dibutuhkan pakan sebanyak $1,311 \mathrm{~kg}$. Semakin tinggi nilai FCR dalam budidaya ayam menunjukan semakin rendah efisien pengguna pakan terhadap pertumbuhan daging, Sedangkan semakin rendah nilai FCR menunjukan semakin tinggi tingkat efisien pengguna pakan terhadap pertumbuhan daging ayam. Artinya dalam budidaya ayam selalu diharapkan memiliki nilai FCR serendah mungkin. 
Tidak adanya pengaruh frekuensi pemberian pakan ini lebih disebabkan oleh tingkat konsumsi (feed intake) yang relative sama, sehingga menghasilkan FCR yang sama. Hal ini sejalan dengan pendapat James (2004, dalam Handayani, 2014) yang menyatakan bahwa salah satu faktor yang mempengaruhi nilai FCR adalah feed aditive yang digunakan dalam pakan, sedangkan pada penelitian ini tidak adanya feed addtive, sehingga menghasilkan nilai konversi yang sama.

Selain itu, FCR ditentukan oleh pertambahan berat badan, karena nilai FCR merupakan perbandingan antara jumlah ransum yang dikonsumsi dengan pertambahan berat badan. Pada penelitian ini juga ditemukan ternyata tidak ada perberbedaan yang signifikan pertambahan berat pada penerapan dua frekuensi pemberianpakan ( 3 kali dan 2 kali). Hal inilah juga menyebabkan tidak adanya pengaruh frkuensi pemberian pakan terhadap nilai FCR.

Hasil penelitian ini sejalan dengan penelitian yang dilakukan oleh Julius (2013, dalam Handayani, 2014) bahwa frekuensi pemberian pakan tidak berpengaruh terhadap FCR.

\section{KESIMPULAN}

Frekuensi pemberian pakan tidak berpengaruh terhadap konsumsi pakan, PBBH dan FCR. Rata-rata konsumsi pakan ayam yang dipelihara dengan menggunakan frekuensi pemberian pakan 2 kali adalah 59,33 gram, sedangkan yang menggunakan frekuensi pemberian pakan 3 kali adalahh 59,41. Rata-rata $\mathrm{PBBH}$ ayam yang dipelihara dengan frekuensi pemberian pakan 2 kali adalah 45,29 gram, sedangkan pada ayam yang dipelihara dengan frekuensi pemberian pakan 3 kali adalah 46,21 gram. Nilai FCR frekuensi pemberian pakan 3 kali adalah 1,286, artinya untuk menghasilkan $1 \mathrm{~kg}$ daging membutuhkan pakan sebanyak $1,286 \mathrm{~kg}$. Sedangkan nilai $\mathrm{FCR}$ ayam pada frekuensi pemberian pakan 2 kali adalah $1,311 \mathrm{~kg}$, artinya untuk menghasilkan $1 \mathrm{~kg}$ daging membutuhkan pakan sebanyak $1,311 \mathrm{~kg}$.

\section{DAFTAR PUSTAKA}

Badan Pusat Statistik Indonesia. 2016. Statistik Indonesia 2016. Badan Pusat Statistik Indonesia. Jakarta. $720 \mathrm{hlm}$.

Badan Pusat Statistik Propinsi Lampung. 2016. Propinsi Lampung dalam Angka 2016. Badan Pusat Statistik Propinsi Lampung. Lampung. $319 \mathrm{hlm}$.

Betty, H., R. Novita dan T. Karyono. 2015. Pengaruh jenis dan waktu pemberian ransum terhadap performans pertumbuhan dan produksi ayam broiler. J. Sains Peternakan Indonesia. 10 (2): 107-113

Handayani, I. 2014. Efisiensi Ekonomi Frekuensi Pemberian Pakan Pada Pemeliharaan Ayam Broiler. Skripsi. Jurusan Sosial Ekonomi Peternakan Fakultas Peternakan. Universitas Hasanudin.

Idayat, A. U. Atmomarsono, W. Sarengat 2012. Pengaruh Berbagai Frekuensi Pemberian Pakan Pada Pembatasan Pakan Terhadap Performans Ayam Broiler. Skripsi. Fakultas Peternakan dan Pertanian, Universitas Diponegoro. Semarang.

James, R. G. 2004. Modern livestock and Poultry Production. 7th Edition. Thomson Delmar Learning Inc., FFA Activities, London. 
Kartasudjana, R. 2005. Manajemen Ternak Unggas. Fakultas Peternakan. Universitas Padjajaran, Bandung.

Pemberian Pakan dan Awal Pemberian Pakan terhadap Performa Ayam Buras Super. Jurnal Sain Peternakan Indonesia Vol. 12 No. 2 April-Juni 2017.

Rasyaf. 2006. Beternak Ayam Pedaging. Penebar Swadaya. Jakarta. 